\title{
БАЛАНС ФЕРУМУ ТА МІДІ В ОРГАНІЗМІ СВИНЕЙ ПРИ ВИКОРИСТАННІ НЕТРАДИЦІЙНИХ ПРИРОДНИХ ДОБАВОК
}

Вербельчук Тетяна Василівна кандидат сільськогосподарських наук, доцент Поліський національний університет

ORCID: 0000-0001-7334-4507

Email: ver-ba555@ukr.net

Вербельчук Сергій Петрович кандидат сільськогосподарських наук, доцент Поліський національний університет ORCID: 0000-0002-1136-5617 Email: verba5551@ukr.net

Ковальчук Ірина Ігорівна кандидат ветеринарних наук, доцент Поліський національний університет ORCID: ORCID: 0000-0002-2421-7533

Email: kovalchuk_ira0982@ukr.net

Ковальчук Ігор Васильович кандидат сільськогосподарських наук, доцент Поліський національний університет ORCID: 0000-0002-5775-4140 Email: ikovalchuk_08@ukr.net

Васильєв Руслан Олександрович кандидат сільськогосподарських наук, ст. викладач Поліський національний університет

ORCID: 0000-0002-1032-9972 Email: kafedra_tvpt@ukr.net

Клим Василь Романович

студент магістратури технологічного факультету Поліський національний університет ORCID: 0000-0003-3964-0737 Email: Klymvaxa@gmail.com

У статті представлені результати використання впливу нетрадиційних природних мінеральних добавок - каолінового та алунітового борошна на середньодобовий баланс мінеральних елементів феруму та міді в організмі свиней. В результаті проведених досліджень встановлено, що використання раціонів, складених в господарстві із сировини місцевого виробництва та нетрадиційних природних мінеральних добавок - каолінового та алунітового борошна, при відгодівлі молодняку свиней забезпечило ефективне використання мінеральних речовин раціонів, що сприяло більш інтенсивному росту тварин та зниженню витрат кормів на виробництво одиниці продукції. Було проведено науковогосподарські дослідження в умовах ВАТ «Колодянський бекон» Новоград-Волинського району Житомирської області. На 4 групах молодняку свиней великої білої породи по 15 голів в кожній. Контрольна група отримувала основний раціон, збалансований за мінеральним складом традиційними солями макро- та мікроелементів. Другій групі згодовували 1,5 \% алунітового та 1,5 \% каолінового борошна від сухої речовини основного раціону. Третій та четвертій групам відповідно 3 \% від сухої речовини раціону каолінового та алунітового борошна, яке згодовували в суміші з концентрованими кормами. Вивчення балансу заліза та міді у організмі тварин проведено одночасно з вивченням перетравності поживних речовин. Обмін феруму в організмі молодняку свиней показав, що з кормами раціону 2, 3 і 4-та дослідні групи споживали заліза порівняно з контролем на 1,17, 0,4 і 1,95 мг більше. Використання феруму по відношенню до кількості прийнятого з кормами, у молодняку свиней 2-ї дослідної групи вище за контроль на 4,9 \% , 3-ї - на 2,8 \% та 4-ї дослідної групи - на 5,7 \% $(P<0,05)$. Введення до раціонів каолінового та алунітового борошна підвищило вміст міді в середньому до 23,02 мг на добу, тобто концентрація ії зросла на 0,17 \%, що обумовило особливості обміну міді в організмі тварин. Відкладання міді в тілі тварин зросло при додаванні суміші каолінового та алунітового борошна на 1,5 мг (P<0,05), більше порівняно 3 контрольною групою. Введення суміші каолінового та алунітового борошна в кількості по 1,5 \% від сухої речовини раціону сприяє підвищенню засвоєння фреруму на 10,7 \% (P<0,001), міді - на 20,0\% \% (P<0,05).

Вісник Сумського національного аграрного університету 
Ключові слова: свині, годівля, природні добавки, алуніт, каолін, ферум, мідь, обмін.

DOI: https://doi.org/10.32845/bsnau.lvst.2021.2.11

Продуктивність свиней різних технологічних груп визначається рядом факторів, зокрема, організацією раціональної та збалансованої годівлі тварин. Повноцінна годівля залежить від створення результативної кормової бази, складання раціонів відповідно до віку та фізіологічного стану, а також від застосування сучасних систем годівлі.

Підвищення рівня приростів поросят, їх загальної резистентності, збереження життєздатності, а також відтворної функції свиноматок та кнурів, що $€$ основою збільшення поголів'я - досягається шляхом збалансованості раціонів [9].

Традиційно, раціони сільськогосподарських тварин нормують за вмістом обмінної енергії, сухої речовини, сирого жиру, сирої клітковини, сирого та перетравного протеїну, макро- та мікроелементів, вітамінів [6]. Варто зазначити, що мінеральне живлення тварин залежить від вмісту мінералів у кормах та воді, а кількість їх в останніх - від типу ґрунтів, виду рослин, технології заготівлі (виробництва) та зберігання тощо. Саме тому, досить часто, спостерігається дисбаланс між рівнем мікроелементів в організмі тварин [11].

Важливого значення при нормованій годівлі свиней набуває забезпечення потреби у мікро- та макроелементах [11].

Халак В. І. [12] зі співавторами зазначає, що згодовування кормів, склад яких не задовольняє фізіологічну потребу тварин у поживних речовинах, сприяє розвитку десіциту каротину на 40-60 \%, фосфору і сірки - 20-40, лізину - 24-35, метіоніну - 11-22, Cu - 10-54, Zn - 14-47, $\mathrm{Mn}-34-45$, Со - 30-40, I - 32-45\%. Крім того, незбалансованість раціону знижує середньодобові прирости в межах 30-35 \% та збільшує витрати кормів на одиницю продукції на $50 \%$.

Pomar, C. та Remus, A. [15] вказують на те, що поліпшенню засвоюваності мінеральних речовин сприятиме метод «точної годівлі», який забезпечує: систему моніторингу кормів поза фермами в умовах реального часу, вчасне виявлення та ліквідацію захворювань і стрес-факторів у свиней, підвищення загального рівня ефективності використання речовин .

Потреба свиней у мінеральних елементах визначається їх екскрецією з калом, сечею, молоком. Натомість рівень споживання - затримкою в організмі на 1 кг приросту живої ваги. Отже, загальна потреба буде дорівнювати сумарному значенню кількості, яка необхідна для життєдіяльності організму та кількості засвоєного певного мінерального елемента [16].

Мікроелементи надходять до організму свиней у вигляді неорганічних солей. Проте, в останні роки набуло поширення використання нетрадиційних мінеральних добавок.

Оскільки мікроелементи входять до складу ферментів, гормонів, вітамінів та інших органічних сполук, то їх основна функція полягає у забезпеченні біохімічних процесів в організмі тварин, де вони виконують роль активатора або ж інгібітора [5, 11].

Серед мікроелементів, які суттєво впливають на стан здоров'я поросят, їх подальший ріст і розвиток, обмінні процеси чільне місце належить феруму. Він входить до складу таких сполук як: гемоглобін, міоглобін, гемосидерин та ін. Бере участь в кровотворенні та обмінних процесах [10, 13].
Низький рівень забезпечення ферумом у постнатальному періоді онтогенезу сприяє розвитку анемії, затримці росту і розвитку, втраті апетиту, підвищенню показників летальності серед поросят-сисунів тощо [3, 14, 17].

Не менш важливим мікроелементом є мідь. Ї̈̈ вплив на організм пов'язаний із формуванням імунітету у тварин, регуляторною функцією роботи центральної нервової та серцево-судинної систем. За участі міді утворюється колаген, забезпечується еластичність судин, відбувається дозрівання еритроцитів [1, 4].

За даними Бережнюк Н. А. та Чорнолата Л. П. [2], спостерігається залежність засвоєння феруму від вмісту в раціоні міді, - засвоєння заліза збільшується з підвищенням ії вмісту в раціоні. Крім того, додавання феруму до раціону з високим вмістом міді сприяє підвищенню рівня гемоглобіну, а також має позитивний вплив на динаміку росту поросят.

Тому дослідження використання нетрадиційних мінеральних добавок у годівлі свиней $є$ актуальним завданням.

Метою дослідження було вивчення впливу природних нетрадиційних добавок в раціонах на обмін заліза та міді в організмі молодняку свиней на відгодівлі.

Матеріали і методи досліджень. Для досягнення поставленої мети, нами було проведено науковогосподарські дослідження в умовах ВАТ «Колодянський бекон» Новоград-Волинського району Житомирської області. Для проведення досліджень методом груп, за принципом пар-аналогів було сформовано 4 групи молодняку свиней великої білої породи по 15 голів в кожній, з врахуванням віку, живої маси, походження, статі та вгодованості поросят [7]. Контрольна група тварин під час зрівняльного та основного періодів отримувала основний раціон. Дослідні групи тварин в основний період досліду до основного раціону отримували додатково нетрадиційні природні мінеральні добавки у вигляді каолінового та алунітового борошна, за розробленою схемою дослідження. Перша група - контрольна в період досліджень отримувала основний раціон годівлі, який за мінеральним складом балансували традиційними солями макро та мікроелементів. Друга група дослідна, якій до основного раціону додавали по 1,5\% суміші каолінового і алунітового борошна від сухої речовини раціону, третя група - 3 \% каолінового борошно та четверта група - $3 \%$ алунітового борошна від сухої речовини раціону. Каолінове та алунітове борошно згодовували двічі на добу у суміші з концентрованими кормами

Годівля тварин проводилася 3 врахуванням живої маси та запланованих середньодобових приростів. В раціони свиней включались найбільш типові для зони Полісся України концентровані корми. До складу комбікорму входили: дерть ячмінна, кукурудзяна, пшенична, горохова, вівсяна, макуха соняшникова, сінне борошно конюшини червоної першого укосу, мінеральні добавки (сіль кухонна, крейда кормова, дикальційсоссфат).

В кінці науково-господарського дослідження було проведено фізіологічний експеримент на чотирьох групах тварин по три голови з кожної групи для вивчення перетравності та засвоюваності поживних речовин, а також обміну азоту та мінеральних елементів за загальноприйнятими методиками [7].

Вісник Сумського національного аграрного університету 
Цифрові дані статистично обробляли за допомогою комп'ютерної програми «Microsoft Excel».

Результати досліджень. Вивчення балансу феруму та міді у організмі тварин проведено одночасно з вивченням перетравності поживних речовин.

В організмі тварин вміст фреруму становить близько 0,005 \% від загальної живої маси, зокрема 90 \% всього феруму сполучено з білками [8].

Для забезпечення потреби організму тварин ферумом рекомендуються встановлені дози сірчанокислого феруму для поросят - 8-10 мг на добу [6]. Вивчення обміну мікроелементу в організмі молодняку свиней показало, що з кормами раціону 2, 3 і 4-та дослідні групи споживали його на 1,17, 0,4 і 1,95 мг більше, порівняно з контролем (табл. 1). Неоднакові рівні споживання піддослідним молодняком свиней зумовили різницю у показниках виділення його 3 організму. Так, якщо у тварин контрольної групи його виділялося з калом 81,2 мг, то у тварин 2-ї дослідної групи $73,4$ мг, або на 9,6 \% менше ( $p<0,05), 3-і ̈-78,5$ мг, або - на 3,3 \% менше та 4-ї дослідної групи 74,7 мг, або - на 8,0 \% менше $(p<0,05)$.

Середньодобовий баланс фреруму в організмі молодняку свиней, $\mathrm{M} \pm \mathrm{m}, \mathrm{n}=3$

\begin{tabular}{|c|c|c|c|c|}
\hline \multirow{2}{*}{ Показник } & \multicolumn{4}{|c|}{ Група } \\
\hline & 1-контрольна & 2-дослідна & 3-дослідна & 4-дослідна \\
\hline \multicolumn{5}{|c|}{ в середині досліджень } \\
\hline Спожито з кормами, мг & 180,0 & 181,17 & 180,4 & 181,95 \\
\hline Виділено з калом, мг & $81,2 \pm 1,23$ & $73,4 \pm 1,32^{*}$ & $78,5 \pm 1,08$ & $74,7 \pm 1,40^{*}$ \\
\hline Виділено з сечею, мг & $2,5 \pm 0,11$ & $2,2 \pm 0,07$ & $2,1 \pm 0,18$ & $2,4 \pm 0,05$ \\
\hline Відкладено в організмі, мг & $96,3 \pm 1,26$ & $105,6 \pm 1,14^{* *}$ & $99,8 \pm 1,33$ & $104,9 \pm 1,39^{\star *}$ \\
\hline Використано від спожитого, \% & $53,5 \pm 1,6$ & $58,3 \pm 1,1^{*}$ & $55,3 \pm 1,6$ & $57,6 \pm 0,8$ \\
\hline \multicolumn{5}{|c|}{ в кінці досліджень } \\
\hline Спожито з кормами, мг & 252 & 253,92 & 252,63 & 255,21 \\
\hline Виділено з калом, мг & $123,2 \pm 1,30$ & $111,8 \pm 1,18^{\star *}$ & $116,9 \pm 1,42^{*}$ & $110,7 \pm 1,39^{\star \star}$ \\
\hline Виділено з сечею, мг & $2,7 \pm 0,09$ & $2,5 \pm 0,14$ & $2,3 \pm 1,36$ & $2,4 \pm 1,47$ \\
\hline Відкладено в організмі, мг & $126,1 \pm 1,17$ & $139,6 \pm 1,10^{* * *}$ & $133,4 \pm 1,42^{*}$ & $142,1 \pm 1,46^{\star *}$ \\
\hline Використано від спожитого, \% & $50,0 \pm 1,5$ & $54,9 \pm 1,2^{*}$ & $52,8 \pm 1,3$ & $55,7 \pm 0,9^{*}$ \\
\hline
\end{tabular}

Примітка: тут і надалі показана різниця вірогідності порівняно з контролем "

Виділення феруму з сечею і калом відповідно, у контрольній групі на 7,8 мг і 0,3 мг, або $12 \%$ більше ніж у 2-й групі, на 2,7 мг і 0,4 мг, або $16 \%$ в 3-й групі і в 4-й групі - на 6,5 мг, або 8,05 \% і 0,1 мг, або $4 \%$.

Найменше феруму відкладалося у молодняку свиней контрольної групи, що залежало від його вмісту в раціоні і становило 53,5 \% від спожитої кількості. У тварин 2, 3 і 4-ї дослідних груп відносний баланс феруму в тілі становив, відповідно - 58,3; 55,3 і 57,6 \% від спожитої кількості.

Використання феруму по відношенню до кількості прийнятого його з кормами, у молодняку свиней 2-ї дослідної групи вище за контроль на 4,9 \% , 3-ї - на 2,8 \% та 4ї дослідної групи - на 5,7 \%.

На основі результатів наведених в табл. 1 можна відмітити, що в тварин дослідних груп в середині і на кінець досліджень із калом виділено менше феруму - різниця достовірна $(\mathrm{P}<0,05)$, відповідно перетравлено більше різниця теж достовірна $(P<0,05)$. Це вказує на те, що поряд із позитивним балансом феруму спостерігається вища ступінь його відкладання в організмі тварин.

Мідь - один з найважливіших незамінних мікроелементів, основна частина якого сконцентрована в м'язах і кістках, крові, печінці, нирках та мозку [8]. Тому достатнє надходження міді в організм тварин регулює роботу життєво-важливих органів і всього організму в цілому.

Аналізуючи одержані дані вивчення балансу міді, слід зауважити, що раціон, складений на основі зернових компонентів 3 додаванням традиційних солей макро- та мікроелементів виявився з меншим рівнем міді. 3 основними кормами тварини споживали лише 23,0 мг міді. Введення до раціонів каолінового та алунітового борошна підвищило вміст міді в середньому до 23,02 мг на добу, тобто концентрація її зросла на 0,17\%. Це значною мірою обумовило особливості обміну міді у тварин. Результати проведених досліджень наведені в табл. 2.

Середньодобовий баланс міді в організмі молодняку свиней, $\mathrm{M} \pm \mathrm{m}, \mathrm{n}=3$

\begin{tabular}{|c|c|c|c|c|}
\hline \multirow{2}{*}{ Показник } & \multicolumn{4}{|c|}{ Група } \\
\hline & 1-контрольна & 2-дослідна & 3-дослідна & 4-дослідна \\
\hline \multicolumn{5}{|c|}{ в середині досліджень } \\
\hline Спожито з кормами, мг & 23,0 & 23,02 & 23,01 & 23,04 \\
\hline Виділено з калом, мг & $14,6 \pm 0,31$ & $13,2 \pm 0,37^{*}$ & $14,4 \pm 0,20$ & $13,6 \pm 0,35$ \\
\hline Виділено з сечею, мг & $0,9 \pm 0,09$ & $0,8 \pm 0,14$ & $0,8 \pm 0,3$ & $0,8 \pm 0,22$ \\
\hline Відкладено в організмі, мг & $7,5 \pm 0,23$ & $9,0 \pm 0,36^{*}$ & $7,8 \pm 0,27$ & $8,6 \pm 0,16^{*}$ \\
\hline Використано від спожитого, \% & $32,7 \pm 1,5$ & $39,2 \pm 2,7$ & $33,8 \pm 3,1$ & $37,2 \pm 1,9$ \\
\hline \multicolumn{5}{|c|}{ в кінці досліджень } \\
\hline Спожито з кормами, мг & 33,5 & 33,62 & 33,57 & 33,60 \\
\hline Виділено з калом, мг & $23,2 \pm 0,27$ & $20,8 \pm 0,32^{* *}$ & $22,4 \pm 0,22$ & $22,5 \pm 0,38$ \\
\hline Виділено з сечею, мг & $1,1 \pm 0,15$ & $1,0 \pm 0,08$ & $1,1 \pm 0,33$ & $1,1 \pm 0,25$ \\
\hline Відкладено в організмі, мг & $9,2 \pm 0,16$ & $11,7 \pm 0,34^{* *}$ & $10,1 \pm 0,23^{*}$ & $10,0 \pm 0,30$ \\
\hline Використано від спожитого, \% & $27,5 \pm 2,08$ & $34,8 \pm 2,52$ & $30,1 \pm 3,11$ & $29,7 \pm 1,87$ \\
\hline
\end{tabular}


Молодняк свиней на відгодівлі усіх піддослідних груп щодоби споживав з кормами у середньому практично однакову кількість міді -23,0-23,07 мг. Однак, щодо виділення міді з продуктами обміну, то у дослідних і контрольних тварин воно дещо відрізнялося. Так, з калом у тварин контрольної групи виділялося 14,6 мг міді, тоді як у тварин 2, 3 і 4-ї дослідних груп, відповідно, на 1,4; 0,2 і 1,0 мг, або 9,59; 1,37 і 6,85 \% менше. Найбільше міді виділено з сечею в тварин 1-ї групи - 0,9 мг. В 2-й дослідній групі відмічено найменше виділення міді як з калом, так і сечею, відповідно 1,4 мг $(p<0,05)$ та 0,1 мг менше ніж в тварин контрольної групи. В 3-й дослідній групі з калом виділено міді менше ніж в контрольній групі на 0,2 мг, або 1,51 \%, але більше ніж в 2й на 1,2 мг, або 8,61\%. Аналогічна ситуація відмічена із виділенням сечі. При згодовуванні алунітового борошна в 4й групі виділення з калом і сечею було менше ніж в 3-й та 1й групі, але більше ніж в 2-й дослідній групі при згодовуванні суміші каолінового та алунітового борошна.

Відкладання міді в тілі тварин зросло при додаванні суміші каолінового та алунітового борошна на 1,5 мг $(P<0,05)$, тобто на 20,0 \% більше порівняно 3 контрольною групою, при додаванні каолінового борошна - на 0,3 мг, або на 4,0 \% порівняно з 1-ю групою і на 1,2 мг, або $14 \%$ менше порівняно з 2-ю групою, а при додаванні алунітового борошна відповідно - на 1,1 мг $(\mathrm{P}<0,05)$ більше міді ніж в 1-й групі, на 0,4 мг (5,19\%) менше ніж в 2-й дослідній групі та на 0,8 мг (10,26 \%) більше ніж в 3-й дослідній групі.

Найбільше використання міді в організмі тварин від спожитого відмічено в 2-й групі -39,2 \% та в 4-й -37,2 \%, що відповідно більше на 6,5 та 4,5\% порівняно з контролем, а 3-тя дослідна група займала проміжне положення між 2 та 4ю дослідними групами.

Вивчення обміну міді в організмі піддослідних тварин на кінець досліджень показало, що з кормами раціону молодняк свиней 2, 3 і 4-ї дослідних груп споживання міді порівняно з контролем на 0,12 мг, 0,07 і 0,1 мг більше (табл. 2).

Так, тварини контрольної групи споживали міді на рівні 33,5 мг, а молодняк свиней 2, 3 та 4-ї дослідних груп відповідно 33,57-33,62 мг .

Не дивлячись на те, що молодняк свиней 2-ї дослідної групи отримував міді на 0,12 мг більше від тварин контрольної групи, але екскреція її з калом у них була меншою на 2,4 мг ( $p<0,01)$, в порівнянні з 3-ю дослідною групою на 1,6 мг $(7,7 \%)$ менше та 4-ї дослідною групою на 1,7 мг $(8,17 \%)$ ніж у молодняку свиней контрольної групи. Щодо екскреції міді з калом у тварин 3-ї дослідної групи, то вона була меншою від контролю всього на 0,8 мг і на 0,1 мг менше, ніж у тварин 4-ї дослідної групи.

Виділення міді з сечею у молодняку свиней 2-ї дослідної групи теж було меншим у порівнянні з контролем на 0,1 мг, або 9,09 \%. Відносне відкладання міді щодо спожитої кількості у тварин 2-ї дослідної групи порівняно з контролем зросло на 2,5 мг $($ p<0,01). У тварин 3-ї дослідної групи за споживання 33,57 мг міді відкладання ії у тілі зросло порівняно 3 контролем на 0,9 мг $(p<0,05)$, а порівняно 3 аналогами 4-ї дослідної групи збільшилося на 0,1 мг.

Слід відмітити, що введення в раціони молодняку свиней на відгодівлі нетрадиційних природних мінеральних добавок - каолінового та алунітового борошна сприяло збільшенню вмісту міді в раціонах дослідних групах порівняно 3 контролем, в середині досліджень він становив від 23,01-23,07 мг і 33,57-33,62 мг в кінці досліджень.

Аналізуючи зміни в обміні феруму та міді, можна зробити висновки, що нетрадиційні природні добавки мають вплив на засвоєння даних елементів в організмі молодняку свиней. При цьому, найвищі показники засвоєння цих мікроелементів були у тварин 2 і 4-ї дослідних груп, яким згодовували нетрадиційні мінеральні добавки в суміші та окремо.

Висновки. Встановлено, що використання нетрадиційних, природних мінеральних добавок позитивно впливає на продуктивну дію кормів раціонів. Збагачення комбікормів відгодівельного молодняку свиней нетрадиційними мінеральними добавками - алунітовим та каоліновим борошном сприяє підвищенню засвоєння заліза та міді у їх організмі. Введення суміші каолінового та алунітового борошна в кількості по 1,5 \% від сухої речовини раціону сприяє підвищенню засвоєння феруму на 10,7 \% ( $\mathrm{P}<0,001)$, міді на $20,0 \%$ \% (P<0,05). Позитивний вплив на обмінні процеси у тварин пояснюється наявністю мікро- та макроелементів у їх складі, фрізико-хімічними властивостями завдяки адсорбції та іонному обміну, а також наявністю в їх складі неідентифрікованого фактору росту.

\section{Список використаної літератури:}

1. Баланс заліза та міді у молодняку свиней за різних преміксів у повнораціонних комбікормах / Н. В. Новгородська та ін. Вінницький національний аграрний університет. Випуск 6 (46). 2011. С. 53-56.

2. Бережнюк Н. А., Чорнолата Л. П. Балансування мінерального живлення свиней. Аграрна наука та харчові технології. Вінницький національний аграрний університет. Випуск 5 (99). Том 1. 2017. С. $23-29$.

3. Білявцева В. В. Продуктивність молодняку свиней за згодовування білково-вітамінно-мінеральної добавки «Енервік» : дис. к. с.-г. наук : 06.02.02 / Біла Церква, 2017. 162 с.

4. Біологія продуктивності сільськогосподарських тварин : підручник / Горбатенко І. Ю. та ін.; за ред. М. І. Гиль. МНАУ. Миколаїв : Видавничий дім «Гельветика», 2018. 600 с.

5. Біохімічні основи нормування мінерального живлення великої рогатої худоби. 2. Мікроелементи / В. В. Влізло та ін. Біологія тварин. 2006. Т. 8, № 1-2. С. 41-62.

6. Бомко В. С., Бабенко С. П., Москалик О. Ю. Годівля сільськогосподарських тварин : підручник. Київ, 2009. 240 с.

7. Вербельчук Т. В., Вербельчук С. П. Обмін азоту і мінеральних елементів в організмі молодняку свиней при використанні окремих нетрадиційних кормових добавок. Вісник Сумського НАУ. Серія: «Тваринництво». 2012. Вип. 12 (21). С. 110-113.

8. Детергенти сучасності : монографія / В. А. Бурлака, І. Г. Грабар, В. М. Микитюк та ін. ; за ред. В. А. Бурлаки. Житомир : ЖНАЕУ, 2012. $652 \mathrm{c}$.

9. Значення і контроль вітамінного живлення свиней. Єфімов В. Г., Софонова Д. М., Тригуб І. Д., Масюк Д. М. Годівля та утримання свиней. 2016. Вип.2. С.17. URL : http://biosafety-center.com/wp-content/uploads/2016/05/4_16.pdf 
10. Клінічна ветеринарна фрармакологія / Канюка О. І. та ін.; за ред. О. І. Канюки. Одеса : Астропринт, 2006. 148 с.

11. Усенко С. О., Сябр, А. С., Березницький В. І., Чухліб Є. В., Слинько, В. Г., Мироненко, О. І. Новітні аспекти мінерального живлення свиней. Вісник Полтавської державної аграрної академії. 2019. № 4. C. 126-133. URL : https://doi.org/10.31210/visnyk2019.04.15

12. Халак В. І., Майстренко А. Н., Дімчя Г. Г. Балансуючі кормові добавки у раціоні свиноматок та поросят. Агробізнес сьогодні. URL : http://agro-business.com.ua/agro/suchasne-tvarynnytstvo/item/8108-balansuyuchi-kormovi-dobavki-u-ratsionisvinomatok-ta-porosyat.html

13. Ganz T. Systemic iron homeostasis. Physiological Reviews. 2013. V. 93(4), 1721-1741. doi: 10.1152/physrev.00008.2013

14. Grushanska N. G. Yakimchuk O.M. Cvilihovskiy M.I. Pokaznik obminu mineralnih rechovin v organizmi svinomatok za profilaktiki mikroelementoziv. Naukovi Dopovidi NUBiP Ukrayini. 2018. № 1 (71). URL: http://dx.doi.org/10.31548/dopovidi2018.01.027

15. Pomar C., Remus A. Precision pig feeding: a breakthrough toward sustainability. AnimalFrontiers. 2019. 9 (2), pp. 52-59. doi: 10.1093/af/vfz006.

16. Yokus B., Cakir U. D. Seasonal and physiological variations in serum chemistry and mineral concentrations in cattle // Biological Trace Element Research. 2006. V. 109, № 3. pp. 255-266.

17. Szudzik M., Starzynski R. R., Jonczy A., Mazgaj R., Lenartowicz M., Lipinski, P. IronSupplementation in Suckling Piglets: An Ostensibly Easy Therapy of Neonatal Iron Deficiency Anemia. Pharmaceuticals (Basel). 2018. 11 (4): 128. doi: 10.3390/ph11040128.

\section{References:}

1. Novhorodska, N. V., Lotka, H. I., Bondar, A. M., Pohrebna, V. P. and Yefimchuk, S. M. 2011. Balans zaliza ta midi u molodniaku svynei za riznykh premiksiv u povnoratsionnykh kombikormakh [Balance of iron and copper in young pigs with different premixes in complete feeds]. Vinnytskyi natsionalnyi ahrarnyi universytet. Vypusk 6 (46). pp. 53-56.

2. Berezhniuk, N. A., Chornolata, L. P. 2017. Balansuvannia mineralnoho zhyvlennia svynei [Balancing the mineral nutrition of pigs]. Ahrarna nauka ta kharchovi tekhnolohii. Vinnytskyi natsionalnyi ahrarnyi universytet. Vypusk 5 (99). Tom 1. pp. 23-29.

3. Biliavtseva, V. V. 2017. Produktyvnist molodniaku svynei za zghodovuvannia bilkovo-vitaminno-mineralnoi dobavky «Enervik» [Productivity of young pigs for feeding protein-vitamin-mineral supplement «Enervik»] : dys. k. s.-h. nauk : 06.02 .02 / Bila Tserkva, $162 \mathrm{p}$.

4. Horbatenko, I. Yu. ta in. 2018. Biolohiia produktyvnosti silskohospodarskykh tvaryn [Biology of productivity of farm animals] : pidruchnyk. Za red. M. I. Hyl. MNAU. Mykolaiv : Vydavnychyi dim «Helvetyka», 600 p.

5. Vlizlo, V. V., Solohub, L. I., Yanovych, V. H. and Antoniak, H. L. 2006. Biokhimichni osnovy normuvannia mineralnoho zhyvlennia velykoi rohatoi khudoby. 2. Mikroelementy [Biochemical bases of normalization of mineral life of large horny food. 2. Microelements]. Biolohiia tvaryn. T. 8, № 1-2. pp. 41-62.

6. Bomko, V. S., Babenko, S. P. and Moskalyk, O. Yu. 2009. Hodivlia silskohospodarskykh tvaryn [Feeding farm animals] : pidruchnyk. Kyiv. 240 p.

7. Verbelchuk, T. V., Verbelchuk, S. P., 2012. Obmin azotu i mineralnykh elementiv v orhanizmi molodniaku svynei pry vykorystanni okremykh netradytsiinykh kormovykh dobavok. [Metabolism of nitrogen and mineral elements in the body of young pigs using certain non-traditional feed additives]. Visnyk Sumskoho NAU. Seriia «Tvarynnytstvo». Sumy, issue 12 (21), pp. 5-9.

8. Burlaka, V. A., Hrabar, I. H., Mykytiuk, V. M. [et al]. 2012. ed. Burlaky V. A. Deterhenty suchasnosti [Modern detergents]: Monohrafiia. Zhytomyr: ZhNAEU, $652 \mathrm{~s}$.

9.Yefimov, V. H., Sofonova, D. M., Tryhub, I. D. and Masiuk, D. M. 2016. Znachennia i kontrol vitaminnoho zhyvlennia svynei. [Importance and control of vitamin nutrition of pigs] Hodivlia ta utrymannia svynei. Vyp. 2. p. 17. URL : http://biosafetycenter.com/wp-content/uploads/2016/05/4_16.pdf

10. Kaniuka, O. I., Faitelberh-Blank, V.R., Lyzohub, Yu.P. ta in.; za red. Kaniuky, O. I. 2006. Klinichna veterynarna farmakolohiia [Clinical veterinary pharmacology]. Odesa : Astroprynt, $148 \mathrm{p}$.

11. Usenko, S. O., Siabr, A. S., Bereznytskyi V. I., Chukhlib Ye. V., Slynko, V. H. and Myronenko, O. I. 2019. Novitni aspekty mineralnoho zhyvlennia svynei [The latest aspects of mineral nutrition of pigs] Visnyk Poltavskoi derzhavnoi ahrarnoi akademii. № 4. pp. 126-133. URL : https://doi.org/10.31210/visnyk2019.04.15

12. Khalak, V. I., Maistrenko, A. N. and Dimchia, H. H. Balansuiuchi kormovi dobavky u ratsioni svynomatok ta porosiat [Balancing feed additives in the diet of sows and piglets]. Ahrobiznes sohodni. URL : http://agro-business.com.ua/agro/suchasnetvarynnytstvo/item/8108-balansuyuchi-kormovi-dobavki-u-ratsioni-svinomatok-ta-porosyat.html

13. Ganz, T. 2013. Systemic iron homeostasis. Physiological Reviews. V. 93(4), 1721-1741. doi: 10.1152/physrev.00008.2013

14. Grushanska, N. G. Yakimchuk, O. M. Cvilihovskiy, M. I. 2018. Pokaznik obminu mineralnih rechovin v organizmi svinomatok za profilaktiki mikroelementoziv. Naukovi Dopovidi NUBiP Ukrayini. № 1 (71). URL : http://dx.doi.org/10.31548/dopovidi2018.01.027

15. Pomar, C., Remus, A. 2019. Precision pig feeding: a breakthrough toward sustainability. Animal Frontiers. 9 (2), pp. 5259. doi: 10.1093/af/vfz006.

16. Yokus, B., Cakir, U. D. 2006. Seasonal and physiological variations in serum chemistry and mineral concentrations in cattle. Biological Trace Element Research. V. 109, № 3. pp. 255-266. 
17. Szudzik, M., Starzynski, R. R., Jonczy, A., Mazgaj, R., Lenartowicz, M., Lipinski, P. 2018. Iron Supplementation in Suckling Piglets: An Ostensibly Easy Therapy of Neonatal Iron Deficiency Anemia. Pharmaceuticals (Basel). 11 (4): 128. doi: 10.3390/ph11040128.

Verbelchuk Tetiana Vasylivna, Candidate of Agricultural Sciences, Associate Professor

Verbelchuk Serhii Petrovych, Candidate of Agricultural Sciences, Associate Professor

Kovalchuk Iryna Igorevna, candidate of vet. Sciences, Art. teacher

Kovalchuk Igor Vasylovych, Candidate of Agricultural Sciences, Associate Professor

Vasiliev Ruslan Alexandrovich, Candidate of Agricultural Sciences, Art. teacher

Klim Vasily Romanovich, Master's student of the Faculty Technology

Polissia National University (Zhytomyr, Ukraine)

Balance of ferum and copper in the organs of pigs when using non-traditional natural additives

The article presents the results of using the influence of non-traditional natural mineral additives - kaolin and alunite flour on the average daily balance of mineral elements of iron and copper in pigs. As a result of research, it was found that the use of rations made on the farm from locally produced raw materials and non-traditional natural mineral additives - kaolin and alunite flour, in the fattening of young pigs provided efficient use of minerals rations, which contributed to more intensive growth production unit. Scientific and economic research was conducted in the conditions of OJSC «Kolodyansky Bacon» of Novograd-Volyn district of Zhytomyr region. On 4 groups of young pigs of large white breed on 15 heads in everyone. The control group received a basic diet balanced in mineral composition with traditional salts of macro- and microelements. The second group was fed $1.5 \%$ alunite and $1.5 \%$ kaolin flour from the dry matter of the main diet. The third and fourth groups, respectively, $3 \%$ of the dry matter of the diet of kaolin and alunite flour, which was fed in a mixture with concentrated feed. The study of the balance of iron and copper in animals was conducted simultaneously with the study of nutrient digestibility. The metabolism of iron in the body of young pigs showed that with the diet of the 2nd, 3rd and 4th experimental groups consumed iron compared to the control of 1.17, 0.4 and $1.95 \mathrm{mg}$ more. The use of iron in relation to the amount taken with feed in young pigs of the 2 nd experimental group is higher than the control by $4.9 \%$, the $3 r d$ - by $2.8 \%$ and the 4 th experimental group - by $5.7 \%(P<0.05)$. The introduction of kaolin and alunite flour in the diet increased the copper content to an average of $23.02 \mathrm{mg}$ per day, ie its concentration increased by $0.17 \%$, which caused the peculiarities of copper metabolism in animals. Copper deposition in the body of animals increased with the addition of a mixture of kaolin and alunite flour by $1.5 \mathrm{mg}(P<0.05)$, more compared to the control group. The introduction of a mixture of kaolin and alunite flour in the amount of $1.5 \%$ of the dry matter of the diet increases the absorption of iron by $10.7 \%(P<0.001)$, copper - by $20.0 \% \%(P<0.05)$.

Key words: pigs, feeding, natural additives, alunite, kaolin, iron, copper, metabolism.

Дата надходження до редакції: 25.05.2021 р. 